\title{
СТАНДАРТ ДОКАЗУВАННЯ ТА ЙОГО ЗАСТОСУВАННЯ В АДМІНІСТРАТИВНОМУ ПРОЦЕСІ
}

Відповідно до приписів статті 9 Конституції України чинні міжнародні договори, згода на обов'язковість яких надана Верховною Радою України, є частиною національного законодавства України [1].

Україна визнала на своїй територіїдію Конвенціїпро захист прав людини і основоположних свобод 1950 року (далі - Конвенція) і юрисдикцію Європейського суду з прав людини (далі - Суд) в усіх питаннях, що стосуються тлумачення і застосування Конвенції, протоколів до неї та зобов'язання виконувати остаточні рішення Суду в будьяких справах, у яких вона є стороною [2].

Суди застосовують під час розгляду справ Конвенцію та практику Суду як джерело права [3].

Національні суди вирішують справи відповідно до Конституції та законів України, а також міжнародних договорів, згода на обов'язковість яких надана Верховною Радою України, та застосовують принцип верховенства права з урахуванням судової практики Суду. Якщо міжнародним договором, згода на обов'язковість якого надана Верховною Радою України, встановлені інші правила, ніж ті, що встановлені законом, то застосовуються правила міжнародного договору України [4].

Таким чином, за системним правовим аналізом зазначених положень Конституції України, Конвенції, КАС України можна дійти висновку, що національні суди у вирішенні адміністративних справ мають застосовувати Конвенцію, прецедентну практику Суду, в якій тлумачаться принципи (стандарти), що лежать в основі Конвенції, як джерело права. Зокрема, правила Конвенції, прецедентна практика Суду, яка тлумачить такі правила, застосовуються національними судами у разі, якщо вони визначать, що законами України встановлені інші правила.

Отже, беручи до уваги принцип автономності [5] (автономне тлумачення Судом змісту норми у конкретних справах), принцип однакового ставлення (equality of treatment) [6], можна дійти такого правового висновку, що національні суди у разі мотивування своєї позиції у вирішенні спірних питань у конкретній справі мають використовувати відповідні принципи (правила, стандарти), які лежать в основі Конвенції про захист прав людини і основоположних свобод, практику Європейського суду з прав людини, в якій тлумачаться такі принципи (правила, стандарти) міжнародного та європейського права, одночасно дотримуючись національних конституційних стандартів. Це спрямоване на те, щоб гарантувати не теоретичні або ілюзорні права особи, а права, що можна здійснити у практиці та ефективно, зокрема на справедливий судовий розгляд [7].

Відповідно до своєї прецедентної практики Суд в оцінці доказів керується стандартом «поза розумним сумнівом». Таке доведення має випливати із сукупності ознак чи неспростовних презумпцій, досить вагомих, чітких і узгоджених між собою [8]. Тобто, на думку автора, доведення стандарту «поза розумним сумнівом» можна 
«розкласти» 3 правової точки зору на такі його складові елементи: сукупності ознак чи неспростовних презумпцій; досить вагомих; чітких і узгоджених між собою, що породжують відповідні обгрунтовані презумпції факту.

Суд зазначив, що стандарт доведення «поза розумним сумнівом» має автономне значення під час розгляду скарг про порушення передбачених Конвенцією прав. Роль Суду, як слід пам'ятати, полягає в тому, щоб виносити рішення не про кримінальну вину або цивільну відповідальність, а за відповідальність Договірних Держав за Конвенцією. Специфіка її завдання, згідно зі статтею 19 Конвенції, - забезпечити дотримання Договірними державами своїх зобов'язань щодо забезпечення основних прав, закріплених у Конвенції, зумовлює ії підхід до питань доказування і надання доказів [9].

Тому, на думку автора, стандарт «поза розумним сумнівом», який за позицією Суду має автономне значення, може бути застосовано національними судами в адміністративному процесі під час розгляду і вирішення справ, де учасником є орган державної влади, у ході якого національним судом здійснюється, зокрема, правова оцінка його дій (бездіяльності), рішень.

Зважаючи на сформоване у прецедентній практиці Судом поняття «поза розумним сумнівом», на думку автора, має загальний правовий характер. Водночас, як свідчить правовий аналіз судових рішень, національні суди під час розгляду і вирішення справ, зокрема в порядку здійснення адміністративного судочинства, посилаючись на стандарт «поза розумним сумнівом», не розкривають його, враховуючи національні конституційні принципи (стандарти), не визначають обов'язкових «правових елементів», за наявності яких зазначений міжнародний стандарт може бути застосований/реалізований у правовому «полі» нашої держави.

Так, автор у попередній публікації [10, с. 33-40] дійшов висновку, що діяльність органів державної влади в Україні можлива в правовому «полі» держави виключно за сукупною наявністю таких обов'язкових «правових елементів»:

- покладених Конституцієї України чи законами завдань (визначають сферу діяльності органу), компетенції (функції, обов’язків), повноважень (права);

- підстав діяльності, якими є Конституція України, закони України, а в деяких випадках з урахуванням чинних міжнародних договорів, згода на обов'язковість яких надана Верховною Радою України;

- способів діяльності, що визначені Конституцією України та законами, які включають: наявність суб'єктного складу учасників; урегульованість положеннями закону (процесуальними нормами), чітку регламентацію дій учасників щодо їх вчинення, строків (термінів); відповідне оформлення результату за вчиненими діями;

- порядку діяльності, встановленого законом, процесуальних норм (спеціальних та загальних), викладених у законі, які встановлюють і регламентують за наявності відповідних умов, визначених у законі, вчинення дій/прийняття рішень органами державної влади з метою виконання покладених на них завдань, реалізації функцій (обов’язків) і повноважень (прав) відповідно до закону.

При цьому застосування/реалізація стандарту «поза розумним сумнівом» у судовому адміністративному процесі, зокрема в порядку КАС України, має свої особливості порівняно з кримінальним процесом. 
Можна погодитись 3 правовим висновком, якого дійшов Верховний Суд: «Кримінальне процесуальне законодавство України складається з відповідних положень Конституції України, міжнародних договорів, згода на обов'язковість яких надана Верховною Радою України, цього Кодексу та інших законів України. Закони та інші нормативно-правові акти України, положення яких стосуються кримінального провадження, мають відповідати цьому Кодексу. У разі здійснення кримінального провадження не може застосовуватися закон, який суперечить цьому Кодексу. Таким чином, корпус норм КПК свідчить про те, що законодавець визначив повноваження кожного суб'єкта кримінального процесу лише цим Кодексом і виключив будь-яку можливість виводити наявність таких повноважень із положень «інших законів» [11]. Тобто повноваження суб’єктів кримінального процесу (у кримінальному провадженні) визначаються нормами Кримінального процесуального кодексу України, зокрема у досудовому розслідуванні і судовому провадженні.

Водночас суб'єкти адміністративного судового процесу, що здійснюється в порядку КАС України, не зв'язані такими вимогами процесуального закону. Призначенням процесуального закону - КАС України, є виключно визначення юрисдикції і повноважень адміністративних судів та встановлення порядку здійснення судочинства в адміністративних судах [12].

Отже, національний суд під час розгляду і вирішення адміністративної справи у разі надання правової оцінки відповідним діям (бездіяльності)/прийнятим рішенням суб'єктами владних повноважень має приділяти належну увагу дослідженню:

- наявності всіх обов'язкових «правових елементів» у суб'єкта владних повноважень - завдання, компетенції, повноважень, які визначаються Конституцією та відповідними законами України;

- наявності способу та порядку, які визначаються законом, відповідно до яких суб'єктом владних повноважень вчинені чи мають бути вчинені дії та прийняті рішення.

На думку автора, встановлення національними судами під час розгляду і вирішення справ зазначених вище «правових елементів» є лише однією з обов'язкових умов для застосування/реалізації стандарту «поза розумним сумнівом» .

Так, особливістю розгляду і вирішення справ у порядку КАС України є те, що адміністративні суди мають перевіряти рішення, дії чи бездіяльнісь суб'єктів владних повноважень, що оскаржуються, чи прийняті (вчинені) вони відповідно до критеріїв, встановлених у частині 2 статті 2 КАС України [12].

Правове формулювання критеріїв, що передбачають зобов'язання суб'єкта владних повноважень вчиняти діï/приймати рішення на підставі, у межах повноважень та у спосіб, що визначені Конституцією та законами України, а також з використанням повноваження з метою, з якою це повноваження надано, є чітким та з урахуванням запропонованого автором визначення правового змісту зазначених вище обов'язкових «правових елементів» не має ускладнювати їх застосування.

Водночас деякі критерії мають загальний характер i, на жаль, не мають визначених законом стандартів, що ускладнюе їх застосування у разі перевірки адміністративними судами бездіяльності, дій чи рішень вчинених/прийнятих суб'єктами владних повноважень. До таких критеріїв належать, зокрема: безсторонність 
(неупередженість), добросовісність, розсудливість, які мають індивідуальний характер та залежать від розуміння їх змісту конкретною посадовою особою суб’єкта владних повноважень.

Безсторонність (неупередженість) пов'язана з тим, що дії посадових осіб суб’єкта владних повноважень мають бути регламентовані приписами Конституції та нормами закону України. У разі вчинення дій має бути забезпечена їх прозорість, відсутня особиста зацікавленість суб’єкта владних повноважень та зацікавленість у захисті інтересів третіх осіб.

Добросовісність пов'язана з результатами досягнення мети діяльності суб'єкта владних повноважень. Тобто чи виконані суб'єктом владних повноважень приписи Конституції та законів України, що регламентують його діяльність.

Розсудливість - це застосування розсудливості суб'єктом владних повноважень у разі вчинення дій/прийняття рішень, що пов'язана 3 тими межами, які визначив законодавець, та зводитися до чіткого виконання суб’єктом владних повноважень приписів Конституції та законів України.

Критерій «дотримання рівності перед законом, запобігаючи всім формам дискримінації» визначає однаковий підхід суб'єкта владних повноважень до вирішення однакових питань, які виникають у разі застосування однакових норм закону з урахуванням того, що кожний випадок є індивідуальним, де норма закону одна, а обставини - різні.

Критерій, згідно з яким суб'єктом владних повноважень має бути вчинена дія/прийнято рішення пропорційно, зокрема з дотриманням необхідного балансу між будь-якими несприятливими наслідками для прав, свобод та інтересів особи і цілями, на досягнення яких спрямоване це рішення (дія), визначає, що такий суб'єкт зобов'язаний вжити всіх необхідних заходів у правових межах, які мають бути застосовані до конкретних взаємин, щодо дотримання пропорційності - необхідного балансу між наслідками для особи та досягненням мети суб'єкта владних повноважень за вчиненою дією/винесеним рішенням.

Головний зміст критеріїв, що передбачає право особи на участь у процесі вчинення діï/прийняття рішення суб'єктом владних повноважень та своєчасність вчинення дій/ прийняття рішення суб'єктом владних повноважень, тобто протягом розумного строку, зокрема пов'язано з можливістю здійснити всі передбачені законом заходи щодо захисту своїх прав, свобод та законних інтересів особою особисто або через представника.

На думку автора, вочевидь у переліку критеріїв, передбачених у частині 2 статті 2 КАС України, відсутній дуже важливий критерій - перевірки національними судами правомірності реалізації суб’єктом владних повноважень відповідного дискреційного повноваження у конкретній ситуації.

Науковці наголошують на необхідності дотримання суб'єктами владних повноважень розроблених Комітетом Міністрів Ради Свропи принципів здійснення дискреційних повноважень, а саме: мети дискреційного повноваження; об’єктивності та неупередженості; рівності перед законом; пропорційності; розумного часу; застосування вказівок; відкритості вказівок; відступу від вказівок; характеру контролю; утримання правоохоронного органу від дій; повноважень контрольних органів щодо отримання інформації тощо [13]. 
Суд у своєму рішенні від 02.11.2006 року у справі «Волохи проти України» зазначив, що закон має з достатньою чіткістю визначати межі такої дискреції, наданої компетентним органам, і порядок її здійснення з урахуванням законної мети такого заходу, щоб забезпечити особі належний захист від свавільного втручання [14].

Автором у своїх попередніх публікаціях [15] уже було розглянуто питання реалізації суб’єктом владних повноважень - органом доходів і зборів, що надані законом, відповідного дискреційного повноваження. В них дійшов таких висновків.

Є зрозумілим з точки зору органу доходів і зборів України: чим «простіше» $\mathrm{i}$ «загальніше» виписана норма, яка дає право проводити перевірки платників податку, тобто не встановлює будь-яких додаткового порядку чи підстав, не містить посилань на інші норми закону, дає органу доходів і зборів України, посилаючись лише на таку норму як підставу, здійснювати перевірки платників податків, незважаючи на інші норми Податкового кодексу України [15].

Нормами глави 8 Податкового кодексу України встановлено, що у разі виконання органом доходів і зборів України приписів Податкового кодексу України, якими регламентовано правила (підстави, порядок та інше) проведення документальних позапланових перевірок: за наявності відповідних обставин і належно оформлених відповідних документів, а також вчинення посадовими особами органу доходів і зборів України відповідних дій $\epsilon$ беззаперечною підставою для реалізацї органом доходів $i$ зборів України свого права на проведення, зокрема, документальної позапланової перевірки [15].

Нормами статті 78 («Порядок проведення документальних позапланових перевірок») Податкового кодексу України визначено обставини (підстави), наявність однієї з яких дає можливість органу доходів і зборів України реалізувати своє право на проведення документальної позапланової перевірки платника податку. При цьому за наявності однієї з обставин (підстав), визначеної у статті 78 Податкового кодексу України, у органу доходів і зборів України виникає обов'язок щодо реалізації свого права на перевірку платника податку відповідно до підпункту 78.1.1 пункту 78.1 статті 78 Податкового кодексу України [15].

Здійснений автором правовий аналіз наведених вище норм Податкового кодексу України та зазначених вище різних позицій щодо порядку проведення органами доходів і зборів України документальних позапланових перевірок дає можливість стверджувати, що рішення керівника органу доходів і зборів України щодо проведення документальної позапланової перевірки має грунтуватись на результаті комплексного застосування норм Податкового кодексу України, які регламентують підстави призначення, порядок направлення обов'язкового письмового запиту і проведення документальної позапланової перевірки. Тобто документальна позапланова перевірка за наявності обставини, передбаченої підпунктом 78.1.1 пункту 78.1 статті 78 Податкового кодексу України, можлива лише за виконання суб'єктами правовідносин (органом доходів і зборів України та платником податків) відповідного порядку (процедури), встановленого як у статті 73, так і у підпункті 78.1.1 пункту 78.1 статті 78 Податкового кодексу України [15].

Зважаючи на вищевикладене, розроблені Комітетом Міністрів Ради Європи принципи здійснення суб'єктами владних повноважень дискреційних повноважень, пра- 
вової позиції Суду та наведених автором деяких висновків щодо можливості реалізації суб'єктом владних повноважень, на прикладі органу доходів і зборів відповідних дискреційних повноважень, що надані законом, можливо дійти таких грунтовних висновків.

Закон має чітко визначати межі дискреційних повноважень суб'єкта владних повноважень, порядок і спосіб реалізації за наявності відповідних умов (обставин). Отже, законом може бути визначено за наявності відповідних умов (обставин) різні способи і відповідні порядки реалізації дискреційних повноважень суб'єктом владних повноважень. При цьому за наявності відповідних умов (обставин) у суб’єкта владних повноважень не виникає права обрати один із варіантів дій, передбачених законом, а виникає саме обов'язок діяти виключно у відповідний порядок та спосіб, передбачений законом. Відсутність хоча б одного із зазначених складників дискреційних повноважень суб’єкта владних повноважень, визначених законом, - відповідних умов (обставин), порядку та способу реалізації, а також відсутності головних «правових елементів» правосуб'єктності суб'єкта владних повноважень - завдань, компетенції, повноважень, які визначаються Конституцією та відповідними законами України, надає підстави стверджувати про відсутність у такого суб'єкта владних повноважень будь-яких дискреційних повноважень.

Дiї, рішення суб'єкта владних повноважень мають бути вчинені/прийняті за наявності відповідних правових та фактичних підстав. Правові підстави передбачають конкретні пункти і статті законодавчих актів, що порушені особою; фактичні підстави - це наявність за кожним порушенням обставин, доказів, що підтверджують факт такого порушення. Обставини мають Грунтуватись, зокрема, на належних і допустимих доказах.

Прогалини та колізії у законах, пов'язані з організацією і порядком діяльності (правовими основами діяльності) суб'єкта владних повноважень, унеможливлюють реалізацію таким суб’єктом наданих йому дискреційних повноважень, а саме не надають останньому всі можливості у разі наявності порушень з боку особи для забезпечення формування повної та грунтовної доказової бази щодо виявлених порушень.

Таким чином, у разі застосування/реалізації національними судами стандарту «поза розумним сумнівом» у судовому адміністративному процесі в порядку здійснення КАС України має бути, зокрема, досліджена та надана оцінка наявності головних обов'язкових «правових елементів» суб'єкта владних повноважень, відповідність дій (бездіяльності)/прийнятим рішенням суб’єктами владних повноважень до критеріїв, встановлених у частині 2 статті 2 КАС України, та наданих дискреційних повноважень.

Правововим результатом реалізації суб’єктом владних повноважень своїх дій за наявності головних обов'язкових «правових елементів» та відповідних умов (обставин) у спосіб та згідно з порядком, які визначаються законом, за якими була одержана відповідна інформація (фактичні дані), є

Фіксація може здійснюватися суб'єктом владних повноважень у різних передбачених законом формах, зокрема документально, як приклад, акт або довідка перевірки платника податків, які $€$ носіями доказової інформації, що передбачено положеннями статті 86 («Оформлення результатів перевірок») Податкового кодексу України [16]. 
При цьому порушення порядку такої фіксації органом державної влади, зокрема вчинення дій з порушенням встановленого порядку, а також вимог до оформлення, змісту відповідного документа, є підставою для можливого визнання такого носія доказової інформації недопустимим доказом. Це може бути відсутність підписів посадових осіб в акті перевірки, дати його складення, підстав для проведення перевірки відповідно до закону, хоча б у дійсності у виявленому суб'єктом владних повноважень щодо скоєного платником податків порушенні не виникало б сумніву.

Необхідно звернути увагу, що у різних сферах діяльності держави є особливості нормативно-правової регламентації щодо фіксації суб’єктом владних повноважень доказової інформації.

Доказами в кримінальному провадженні є фактичні дані, передбачені у Кримінальному процесуальному кодексі України [17].

Відповідно до частини 1 статті 1 Кримінального процесуального кодексу України порядок кримінального провадження на території України визначається лише кримінальним процесуальним законодавством України, а відповідно до частини 2 цієї статті кримінальне процесуальне законодавство України складається з відповідних положень Конституції України, міжнародних договорів, згода на обов'язковість яких надана Верховною Радою України, цього Кодексу та інших законів України [17].

Зважаючи на це, є очевидним, що кримінальне процесуальне законодавство України не включає в себе підзаконні нормативно-правові акти (зокрема, накази, інструкції органів державної влади тощо). Тобто доказування стороною кримінального провадження з боку обвинувачення та захисту допустимості доказів, які були одержані під час досудового розслідування злочинів, не може грунтуватись на підзаконних нормативно-правових актах. Прикладом такого акта можна навести Iнструкцію про організацію проведення негласних слідчих (розшукових) дій та використання їх результатів у кримінальному провадженні, яка затверджена спільним наказом Генеральної прокуратури України, Міністерства внутрішніх справ України, Служби безпеки України, Адміністрації Державної прикордонної служби України, Міністерства фінансів України, Міністерства юстиції України від 16.11.2012 № 114/1042/516/1199/936/1687/5 [18].

Податковий кодекс України регулює відносини, що виникають у сфері справляння податків і зборів, зокрема, визначає вичерпний перелік податків та зборів, що справляються в Україні, та порядок їх адміністрування, платників податків та зборів, їхні права та обов'язки, компетенцію контролюючих органів, повноваження та обов'язки їхніх посадових осіб під час адміністрування податків, а також відповідальність за порушення податкового законодавства [16].

Відповідно до пункту 3.1. Податкового кодексу України податкове законодавство України складається з Конституції України; Податкового Кодексу; Митного кодексу України та інших законів з питань митної справи у частині регулювання правовідносин, що виникають у зв'язку з оподаткуванням митом операцій з переміщення товарів через митний кордон України (далі - законами з питань митної справи); чинних міжнародних договорів, згода на обов'язковість яких надана Верховною Радою України і якими регулюються питання оподаткування; нормативно-правових актів, прийнятих на підставі та на виконання иього Кодексу та законів з питань митної справи; 
рішень Верховної Ради Автономної Республіки Крим, органів місцевого самоврядування з питань місцевих податків та зборів, прийнятих за правилами, встановленими цим Кодексом [16].

Так, з метою реалізації норм законів України та чіткої регламентації дій органами державної влади можуть бути видані підзаконні нормативно-правові акти. Але за умови, що такі підзаконні нормативно-правові акти мають бути видані органами державної влади виключно у межах своєї компетенції і повноважень, не розширювати, не змінювати (підміняти, спотворювати) норми законів України, на підставі яких вони видані.

Отже, є очевидним, що податкове законодавство України включає в себе нормативно-правові акти, прийняті на підставі та на виконання Подактового кодексу України, зокрема підзаконні нормативно-правові акти (зокрема, накази, порядки органів державної влади та ін.), а тому і доказування допустимості доказів, які були одержані під час діяльності органу державної влади (органів доходів і зборів), може грунтуватись на відповідних підзаконних нормативно-правових актах. Прикладом $є$ Порядок оформлення результатів документальних перевірок дотримання законодавства України з питань державної митної справи, податкового, валютного та іншого законодавства платниками податків - юридичними особами та їх відокремленими підрозділами, який затверджено наказом Міністерства фінансів України від 20.09.2015 № 727 (зареєстрований у Міністерстві юстиції України 26.10.2015 за № 1300/27745) [19].

Як випливає з наведених вище норм законів та прикладів, у різних сферах діяльності держави особливості нормативно-правової регламентації щодо фіксації суб’єктом владних повноважень доказової інформації полягають у тому, що деякі процедурні питання щодо фіксації суб'єктом владних повноважень доказової інформації можуть бути врегульовані підзаконними нормативно-правовими актами, якщо такі акти становлять законодавство у відповідній сфері діяльності держави. При цьому, на думку автора, порушення відповідних процедур, які регламентують дії суб’єкта владних повноважень щодо фіксації доказової інформації, можуть бути підставою для визнання носія доказової інформації недопустимим доказом.

Таким чином, у разі застосування/реалізації національними судами стандарту «поза розумним сумнівом» у судовому адміністративному процесі в порядку здійснення КАС України має бути, зокрема, досліджена та надана оцінка діям суб'єкта владних повноважень щодо обов’язкового дотримання порядку (процедури) щодо фіксації доказової інформації, а саме складання та оформлення носія доказової інформації (джерела доказів).

Стандарт «поза розумним сумнівом» також має включати в себе доведення наявності кожного із складових елементів, які $€$ важливими для правової кваліфікації правопорушення, яке встановлено та зафіксовано суб'єктом владних повноважень, до яких належать суб’єкт, суб’єктивна сторона, об’єкт та об’єктивна сторона.

При цьому необхідно зважати, що порушення сутнісного змісту конституційних прав і свобод людини і громадянина з боку органів державної влади за бездіяльності, вчинення дій/прийняття рішень навіть 3 додержанням усіх законодавчо встановлених механізмів може бути підставою для визнання одержаних доказів недопустимими [10] та неможливості застосування/реалізації стандарту «поза розумним сумнівом» . 
Як зазначив Суд, «завданням національних судів $є$ забезпечення належного вивчення документів, аргументів і доказів, представлених сторонами" (Van de Hurk v. the Netherlands (Ван де Гурк проти Нідерландів), § 59) [20], та відповідно до процесуального закону, а саме КАС України, одержаних за ініціативою адміністративного суду [4].

Звертаючи увагу на вищевикладене, на думку автора, застосування/реалізація національними судами стандарту «поза розумним сумнівом» у судовому адміністративному процесі в порядку здійснення КАС України може бути за наявності таких основних правових умов:

- наявності всіх обов'язкових «правових елементів» у суб'єкта владних повноважень - завдання, компетенції, повноважень, які визначаютья Конституцією та відповідними законами України;

- наявності способу та порядку, які визначаються законом, відповідно до яких суб’єктом владних повноважень вчинені чи мають бути вчинені дії та прийняті рішення;

- дослідження та надання оцінки відповідності дій (бездіяльності)/прийнятим рішенням суб'єктом владних повноважень до критеріїв, встановлених у частині 2 статті 2 КАС України, та наданих дискреційних повноважень;

- дослідження та надання оцінки діям суб'єкта владних повноважень щодо обов'язкового дотримання порядку (процедури) складання та оформлення носія доказової інформації (джерела доказів);

- доведення наявності кожного зі складових елементів, які є важливими для правової кваліфікації правопорушення, яке встановлено та зафіксовано суб'єктом владних повноважень, до яких належать суб'єкт, суб'єктивна сторона, об'єкт та об’єктивна сторона.

Це дасть можливість національним судам, дослідивши під час розгляду і вирішення адміністративної справи, зокрема, наявність вищезазначених основних умов, встановити належність та допустимість доказів, на підставі яких наявність справжніх обставин (фактів) справи, які входять до предмета доказування, що породжують відповідні обгрунтовані презумпції факту.

\section{Jimepamypa}

1. Конституція України. URL: http://zakon4.rada.gov.ua/.

2. Конвенція про захист прав людини і основоположних свобод. URL: https://zakon.rada.gov.ua/ laws/show/995_004.

3. Закон України від 23.02.2006 № 3477-IV «Про виконання рішень та застосування практики Європейського суду з прав людини». URL: https://zakon.rada.gov.ua/laws/show/3477-15.

4. Кодекс адміністративного судочинства України. URL: http://zakon4.rada.gov.ua/.

5. Рішення Європейського Суду з прав людини від 28 червня 1979 року «CASE OF KÖNIG v. GERMANY» URL: http://hudoc.echr.coe.int/eng?i=001-57512.

6. Рішення Європейського Суду з прав людини від 28.05.1993 у справі «Шулер-Цграгґен проти Швейцарії. URL: http://www.scourt.gov.ua/clients/vsu/vsu.nsf/(print)/AC7E4FDEA1043C2AC2258 0F8003E2AFA.

7. Яковенко Є.О. «Правові аспекти здійснення судових викликів і повідомлень в адміністративному процесі». Науковий збірник «Актуальні проблеми вітчизняної юриспрудениї» 2018, № 2, с. 127-133.

8. Рішення Європейського Суду з прав людини від 27 листопада 2008 у справі «Ісмаілов проти України" URL: https://zakon.rada.gov.ua/laws/show/974_486/conv.

9. Рішення Європейського Суду з прав людини від 06 липня 2005 у справі «Начова и другие против Болгарии». URL: https://hudoc.echr.coe.int/eng\#\{\%22fulltext $\% 22:[\% 22$ Nachova $\% 20$ and $\% 20$ 
Others $\%$ 20v. $\%$ 20Bulgaria $\% 22$ ], $\%$ 22documentcollectionid $\%$ 22:[\% 22GRANDCHAMBER $\% 22, \% 22 \mathrm{CH}$ AMBER $\% 22], \%$ 22itemid $\% 22:[\% 22001-69630 \% 22]\}$.

10. Яковенко Є.О. Правові аспекти одержання органами державної влади доказів з дотриманням національних конституційних стандартів. Науковий збірник «Приватне та публічне право». 2019, № 1, c. 33-40.

11. Ухвала Верховного Суду від 06 березня 2018 у справі № 243/6674/17-к. URL: http://www.reyestr.court.gov.ua/Review/72670536.

12. Кодекс адміністративного судочинства України. URL: http://zakon4.rada.gov.ua/.

13. Науковий висновок Верховного Суду щодо меж дискреційного повноваження суб'єкта владних повноважень та судового контролю за його реалізацією. URL: https://supreme.court.gov.ua/supreme/ pro_sud/naukovi_visnovki/nauk_visnovok_01_03_2018.

14. Рішення Європейського суду з прав людини від 02.11 .2006 року у справі «Волохи проти України». URL: https://zakon.rada.gov.ua/laws/show/974 138 .

15. Яковенко Є.О. Актуальні питання проведення органами доходів і зборів України документальної позапланової перевірки платників податків. Вісник Запорізького національного університету, 2014. № 3, c. 179-187.

16. Податковий кодекс України. URL: http://zakon.rada.gov.ua/laws/show/2755-17.

17. Кримінальний процесуальний кодекс України URL: https://zakon.rada.gov.ua/laws/ show/4651-17.

18. Інструкція про організацію проведення негласних слідчих (розшукових) дій та використання їх результатів у кримінальному провадженні, яка затверджена спільним наказом Генеральної прокуратури України, Міністерства внутрішніх справ України, Служби безпеки України, Адміністрації Державної прикордонної служби України, Міністерства фінансів України, Міністерства юстиціі України від 16.11.2012 № 114/1042/516/1199/936/1687/5. URL: https://zakon.rada.gov.ua/laws/ show/v0114900-12.

19. Порядок оформлення результатів документальних перевірок дотримання законодавства України 3 питань державної митної справи, податкового, валютного та іншого законодавства платниками податків - юридичними особами та їх відокремленими підрозділами, який затверджено наказом Miністерства фінансів України від 20.09.2015 № 727 (зареєстрований у Міністерстві юстиції України 26.10.2015 за № 1300/27745). URL: https://zakon.rada.gov.ua/laws/show/z1300-15.

20. Рішення Європейського суду з прав людини від 19.04.1994 у справі «Ван де Гурк проти Нідерландів». URL: https://hudoc.echr.coe.int/eng\#\{\% 22itemid\% 22:[\% 22001-57878\% 22]\}.

\section{Анотація}

Яковенко Є.О.Стандарт доказування та його застосування в адміністративному процесі. - Стаття.

У публікації автором розглянуто можливість та основні правові умови застосування національними судами в адміністративному процесі в порядку здійснення КАС України стандарту, сформованого прецедентною практикою Європейського суду з прав людини, а саме доведення «поза розумним сумнівом» .

Ключові слова: орган державної влади, рішення, дії (бездіяльність), дискреційні повноваження, докази, носій доказової інформації.

\section{Аннотация}

Яковенко E. A. Стандарт доказывания и его применение в административном процессе. - Статья.

В публикации автором рассмотрена возможность и основные правовые условия применения национальными судами в административном процессе в порядке осуществления КАС Украины стандарта, сформированного прецедентной практикой Европейского суда по правам человека, а именно доказательства «вне разумного сомнения».

Ключевые слова: органы государственной власти, решения, действие (бездействие), дискреционные полномочия, доказательства, носитель доказательной информации.

\section{Summary}

Yakovenko Ye. O. Standard of evidence and its application in administrative process. - Article.

In the publication the author considered the possibility and basic legal conditions for the application by national courts in the administrative process in the exercise of the CAS of Ukraine of the standard established by the case-law of the European Court of Human Rights, namely the evidence "beyond reasonable doubt".

Key words: state authorities, actions (inaction), discretionary powers, evidence, evidence carrier. 